\title{
MAKNA SIMBOL DALAM PROSESI PEMINANGAN DI DESA WAENIBE KECAMATAN FENALISELA KABUPATEN BURU UTARA
}

\author{
Prisiska N. Wamnebo \\ Mariana Lewier \\ Novita Tabelessy \\ Email : Priskawamnebo@gmail.com
}

\begin{abstract}
ABSTRAK: Penelitian ini bertujuan mendeskripsikan makna simbol dalam prosesi peminangan di Desa Waenibe Kecamatan Fenalisela Kabupaten Buru Utara. Jenis penelitian ini adalah penelitian kualitatif. Data penelitian ini mengacu pada tuturan lisan berupa kata dan kalimat dari narasumber dalam prosesi peminangan, sedangkan sumber data dalam penelitian ini adalah para informan yang berperan dalam setiap upacara adat, khususnya dalam upacara adat peminangan dan dapat menjelaskan makna simbol dalam peminangan dengan baik. Hasil penelitian menunjukkan bahwa makna simbol yang terdapat dalam proses peminangan di Desa Waenibe melalui (1) pidato awal (orasi), yaitu salam putri, wajah cantik dan kue; (2) pantun, yaitu rumput cinta-rumput sayang, dan (3) nyanyian rakyat, yaitu perahu tanpa semang.
\end{abstract}

Kata Kunci: makna simbol, prosesi peminangan, pidato awal 


\title{
MEANING OF SYMBOLS IN VENDING PROCESSION IN WAENIBE VILLAGE FENALISELA DISTRICT BURU UTARA DISTRICT
}

\author{
Prisiska N. Wamnebo \\ Mariana Lewier \\ Novita Tabelessy \\ Email : Priskawamnebo@gmail.com
}

\begin{abstract}
This study aims to describe the meaning of symbols in the procession of specialization in Waenibe Village, Fenalisela District, Buru Utara District. This type of research is qualitative research. The data of this study refers to oral speech in the form of words and sentences from the speakers in the procession of the specialization, while the data sources in this study are informants who play a role in each traditional ceremony, especially in the special ceremonial ceremony and can explain the meaning of the symbol in favor. The results of the study indicate that the symbol meanings found in the process of specialization in Waenibe Village, is (1) initial speech (oration), namely princess greetings, beautiful faces and cakes; (2) pantun, namely grass love-grass, dear, and (3) singing of the people, which is a boat without semang.
\end{abstract}

Keywords: symbol meanings, specialization procession, initial speech 


\section{A. PENDAHULUAN}

Peminangan merupakan sesuatu yang sakral bagi setiap pasangan hidup yang beradat. Karena itu, peminangan bukan hanya sekadar mengikuti ajaran adat-istiadat dan meneruskan naluri para leluhur untuk membentuk sebuah keluarga dalam ikatan hubungan yang sah antara pria dan wanita, namun juga memiliki arti yang sangat mendalam dan luas bagi kehidupan manusia dalam menuju kehidupan baru seperti yang dicita-citakan.

Peminangan merupakan pendahuluan perkawinan, disyari'atkan sebelum ada ikatan suami istri dengan tujuan agar setelah memasuki perkawinan didasarkan kepada penelitian, kesadaran dan kesadaran masing-masing (Ghozali, 2010:74). Selanjutnya Poerwadarminta (1993:753) menyatakan bahwa meminang berarti meminta anak gadis supaya menjadi istrinya, pinangan permintaan hendak memperistri, sedangkan orang yang meminang disebut peminang. Adapun peminangan adalah perbuatan meminang.

Peminangan bagi masyarakat Desa Waenibe merupakan peristiwa yang sangat penting dan memiliki nilai yang sangat sakral. Melalui peminangan, sesorang akan membentuk keluarga yang baru. Desa Waenibe memiliki tradisi upacara peminangan adat memiliki simbol dan makna yang mendalam. Melalui upacara prosesi peminangan, biasanya melalui upacara masyarakat menggunakan simbol-simbol yang bersifat abstrak, yang masih dalam tingkat pemikiran seseorang atau kelompok, yang sering dikaitkan dengan berbagai kegiatan sosial yang ada pada kehidupan mereka sehari-hari. Simbol juga merupakan sesuatu yang sangat dikenal dan dipahami oleh 
masyarakat dalam kehidupan sehari-hari yang sering dipergunakan sebagai alat untuk mewariskan kebudayaan.

Upacara adat di Desa Waenibe, khususnya pada prosesi peminangan merupakan salah satu upacara sangat penting (acara sebelum diadakannya upacara pernikahan). Prosesi peminangan menyatukan dua pihak keluarga yaitu keluarga calon mempelai laki-laki dan keluarga calon mempelai perempuan. Upacara ini, menghadirkan dua pihak keluarga yang berasal dari daerah yang berbeda-beda dari Pulau Buru, yang tentunya memiliki adat yang berbeda-beda dari ragam bahasa hingga penyampaian dan tujuan pembicaraan. Prosesi peminangan, bagi kedua pihak keluarga dan calon mempelai sangat penting, sehingga dibutuhkan orang-orang yang benar-benar mengetahui bahasa daerah Waenibe untuk memimpin acara peminangan tersebut.

Adapula alasan peneliti melakukan penelitian tentang makna simbol pada prosesi peminangan di Desa Waenibe Kecamatan Finalisela Kabupaten Buru Utara, yaitu (1) karena hingga saat belum ada penelitian menyangkut hal tersebut; (2) penulis memilih Desa Waenibe Kecamatan Finalisela Kabupaten Buru Utara sebagai lokasi penelitian karena masyarakat di Desa Waenibe masih bersifat homogen atau belum dipengaruhi oleh budaya dari luar desa tersebut sehingga memungkinkan peneliti memperoleh data yang asli (3) lebih banyak mengkaji dari segi kesenian, bentuk dan ragam hias, pakaian adat, dan simbol-simbol dalam perkawinan adat. 
Berdasarkan ulasan di atas, maka peneliti tertarik untuk meneliti adalah tentang "Makna Simbol dalam Prosesi Peminangan di Desa Waenibe Kecamata Fenalisela Kabupaten Buru Utara”.

\section{B METODE PENELITIAN}

Dalam penelitian ini, peneliti menggunakan pendekatan kualitatif. Menurut Denzin dan Lincoln (dalam Moleong, 2012:5), penelitian kualitatif adalah penelitian yang menggunakan latar alamiah dengan maksud menafsirkan fenomena yang terjadi dengan melibatkan berbagai metode yang ada. Jadi, dalam penelitian ini peneliti mendeskripsikan secara alamiah data dari proses interaksi dengan objek yang diteliti yaitu penggunaan bahasa Buru pada prosesi peminangan di Desa Waenibe Kecamatan Finalisela. Penelitian ini bersifat deskriptif, yaitu memberikan gambaran secara jelas tentang bagaimana penggunaan bahasa Buru pada prosesi peminangan di Desa Waenibe Kecamatan Finalisela Kabupaten Buru Utara.

Penelitian ini dilakukan berdasarkan ciri-ciri penelitian kualitatif menurut Moleong (2012:8-12) di antaranya;

(1) data bersifat alamiah (natural setting). Dalam hal ini data alamiah tetap terkait sepenuhnya dengan konteks, dengan sendirinya unsur-unsur yang terkait dengan konteks misalnya tindakan, ucapan, dan gerak isyarat tidak diabaikan dengan penelitian ini, supaya peneliti tidak kehilangan segala kepentingan yang berhubungan dengan konteks tersebut; 
(2) manusia sebagai instrumen penelitian. Dalam konteks ini manusia bermanfaat untuk menangkap makna dan nilai-nilai lokal yang berbeda. Manusia dikatakan sebagai instrumen penelitian sebab ia merupakan perencana, pelaksana, pengumpulan data, dan pada akhirnya ia menjadi pelapor hasil penelitian;

(3) penelitian bersifat deskriptif, yaitu penelitian berusaha untuk menuturkan pemecahan masalah yang ada sekarang berdasarkan data-data. Jadi, ia juga menyaksikan data, menganalisis dan menginterpretasi;

(4) data yang dikumpulkan cenderung berbentuk kata-kata atau gambaran daripada angka-angka;

(5) analisis data cenderung bersifat induktif. Hal ini dilakukan agar mempermudah pendeskripsian konteks yang muncul setelah peneliti sebelumnya membuat abstraksi yang disusun berdasarkan bukti-bukti yang terkumpul;

(6) lebih mementingkan proses daripada hasil. Penelitian kualitatif lebih banyak mementingkan segi proses daripada hasil. Hal ini disebabkan oleh hubungan bagian-bagian yang sedang diteliti akan jauh lebih jelas apabila diamati dalam proses;

(7) teori dari dasar. Penelitian kualitatif lebih menghendaki arah bimbingan penyusunan teori substantif yang berasal dari data. Analisis ini lebih merupakan pembentukan abstraksi berdasarkan bagian-bagian yang telah dikumpulkan, kemudian dikelompok-kelompokan. Jadi, penyusunan teori di sini berasal dari bawah ke atas yaitu sejumlah data yang banyak dikumpulkan 
dan yang saling berhubungan. Jika peneliti merencanakan untuk menyususn teori, arah penyusunan teori tersebut akan menjadi jelas sesudah data dikumpulkan. Jadi, peneliti dalam hal ini menyusun atau membuat gambaran yang makin menjadi jelas sementara data dikumpulkan dan bagian-bagiannya diuji. Ketujuh karakteristik tersebut relevan dengan penelitian ini

\section{PEMBAHASAN}

Pidato atau orasi awal ini dapat dilihat pada tahap pelaksanaan perkawinan, setibanya mempelai laki-laki dan keluarganya disambut dengan jabatan tangan antara pengantin laki-laki dan juru bicara dari pengantin perempuan. Ketika berjabat tangan, juru bicara perempuan menyampaikan pidato (orasi) awal yaitu sebagai berikut:

Kura ngadat kawasan wakolo

Anika kae kawasan tunam salamat putrir lima

Rupan gosa gandi ngan, ngan gosa gandi lagam

Bunasarika baikole bunaniolo ange rese

Rese-rese doku dohi, rese mo doku dohi

Makna simbol yang terdapat pada pidato atau orasi awal yaitu pada kalimat di bawah ini:

Salamat putrir

Salam putri

"Salam putri"

Salam : Kata salam, demikian juga kata shalam dan selamat, maknanya berkisar pada kedamaian, kesejahteraan, dan keselamatan atau keterhindaran dari segala yang tercela. 
Putri : Anak yang menawan, anak yang baik hati, anak perempuan yang cantik.

Makna yang tersirat pada kalimat di atas adalah bentuk sapaan yang penuh rasa kekeluargaan, penghargaan, penghormatan, dan penuh kedamaian yang disampaikan oleh tua adat pihak mempelai laki-laki kepada juru bicara pihak pengantin perempuan dengan maksud yang baik sebelum mereka mengambil pengantin perempuan.

\author{
Rese rese \\ Wajah cantik \\ Rese mo \\ Nama indah
}

Makna yang tersirat pada kalimat "rese-rese, rese mo" merupakan penggambaran terhadap pengantin perempuan yang selain cantik, ia juga berperilaku yang baik. Bisa dilihat langsung dari wajahnya yang cantik dan elok.

\author{
Sapan anga kimba loar kuer fuar lima \\ Gosat kampisan fidi kimi, bukam egopale kormo
}

Makna simbol yang terdapat pada kutipan di atas adalah pada kata "kuer" atau "kue". Kue mengandung makna kesiapan kedua mempelai untuk bekerja sama mengarungi bahtera rumah tangga. Kue juga melambangkan pengaharapan mempelai pengantin dan juga keluarga yang menyimbolkan kesuburan. Dari simbol kesuburan ini diharapkan akan adanya keturunan yang baik dan diharapkan oleh pasangan pengantin ini. Serta kue melambangkan ungkapan kasih sayang dan juga sebuah komitmen bahwa kedua mempelai akan saling menjaga selama-lamanya. 


\title{
1. Makna Simbol pada Pantun
}

Dalam tradisi peminangan di Pulau Buru terkhususnya Desa Waenibe setiap calon pengantin lelaki diwajibkan menyampaikan sebuah pantun sebagai tanda rasa cinta dan rasa sayang kepada pengantin perempuan. Jadi dari pantun itu diharapkan kedua pasangan saling menghormati, saling menjaga, dan memberikan yang terbaik pada pasangan.

\author{
Reana rea cita-rea sayang \\ Dadula boli hawa baban \\ Doeta kimi cinta-tukim sayang \\ Dokimsi toate lakim baban \\ Rumput cinta rumput sayang \\ tumbuh di kebun \\ Sungguh cinta- sungguh sayang \\ Silahkan masuk untuk digendong
}

Makna simbol pada pantun di atas, terdapat pada baris pertama dan baris kedua yaitu sebagai berikut:

\section{Reana reacita- reana sayang \\ Rumput cinta- rumput sayang \\ Dadula boli hawa baban 1}

Makna yang tersirat pada kedua kalimat "Rumput cinta-rumput sayang" dan "Selalu tumbuh di kebun" adalah bahwa bila ada kebun, maka selalu saja ada rumput. Sebaliknya apabila ada cinta, berarti ada juga sayang. Oleh sebab itu, laki-laki dan perempuan, Allah ciptakan dalam format berpasangan, bukan berlawanan atau bermusuhan. Setelah menikah, sebagai pasangan mereka menjadi utuh karena saling melengkapi satu dengan yang lainnya. Pasangan itu bermakna "saling", bukan 
sendirian, dan bukan saling bebas-lepas. Selalu ada pengaruh suami terhadap istri dan ada pengaruh istri terhadap suami. Maka, sebagai pasangan tentu harus bisa saling mengerti, saling menghormati, saling menghargai, saling menjaga, saling memberikan yang terbaik untuk pasangan. Jadi, diharapkan kepada kedua pasangan untuk selalu melandasi hubungan suami-istri dengan penuh rasa cinta dan rasa sayang.

\section{Makna Simbol pada Nyanyian Rakyat}

Ho...he...

Kuma nati gandi nawaga baikole

Damnei gandi wae vavan-wae alat

Dobara olo ngei dae-bara olo ngei lawe

Tubas daiko dovon-dovon

Kuma nati gandi nawaga baikole

Rumah tangga ibarat perahu tanpa semang

Perahu : Perahu selain mempunyai arti sebagai alat transportasi dan komunikasi antar pulau yang menggambarkan kehidupan masyarakat Buru sejak dahulu kala, juga mempunyai arti sebagai suatu kebiasaan adat sesuai fungsi adat masing-masing sekaligus sebagai sarana persatuan dan kesatuan.

Semang : Kayu pengimbang kiri kanan perahu.

Dari penjelasan di atas, makna simbol pada kalimat "perahu tanpa semang" yaitu sebuah rumah tangga yang perlu dijaga keharmonisan dengan tidak melakukan hal-hal yang merugikan antara kedua pasangan baru ini. Keharmonisan ini tercipta melalui saling menghargai dan menghormati antara kedua pasangan sehingga terbentuk keluarga yang bahagia. 
Damnei wae vavanwae alat

Pada permukaan air

Dobara olo ngei dae-bara olo ngei lawe

Tidak boleh miring kiri

Tubas daiko dovon dovon

Semoga selalu berjalan lurus

Ho...he...

Ho...he...

Kae gandi fena dikat do

Kamu telah berada di mata rumah suamimu

Timut nake inar amarro

Berbuatlah ramah terhadap orang tuanya

Gandi namo rese matir dihe

Seperti ayah dan ibu kandungmu

Makna yang tersirat pada baris ketiga dan keempat, berupa sebuah ajakkan kepada pengantin perempuan untuk menghormati orang tua suaminya (orang tua menantu) dalam rumah. Karena (orang tua menantu) merupakan orang tua yang melahirkan suami Anda. Merekalah yang merawat, memberi makan, mendidik dan menyekolahkan suami Anda. Tanpa mereka, suami Anda juga tidak akan bisa berhasil. Maka itu, anggaplah (orang tua menantu) sebagai orang tua Anda sendiri. Perlakukan mereka dengan baik. Berikan kasih sayang dan perhatian serta turuti nasihat mereka.

\section{Makna Simbol dalam Doa}

\section{Baso opo bamaketa tunam huma lalen}

Semoga Tuhan memberkati rumah tanggamu

Makna yang tersirat pada baris kelima, berupa sebuah doa. Doa adalah unsur paling penting dalam sebuah pernikahan. Karena dengan itulah, orang tua dari pengantin perempuan melibatkan dan turut mengundang Tuhan hadir memberkati 
rumah tangga anak perempuan mereka serta membimbing kedua pasangan ini menjadi pribadi yang sesuai dengan kehendak-Nya.

\section{KESIMPULAN}

Makna simbol yang dipakai dalam upacara perkawinan adat di Desa Waenibe Kecamatan Fenalisela Kabupaten Buru Utara terkandung dalam ujaran lisan berupa pidato, pantun, doa, dan nyanyian rakyat.

Pertama, pada tahap pelaksanaan peminangan biasanya juru bicara pihak perempuan menyampaikan pidato (orasi) untuk menyambut atau menyapa keluarga calon pengantin laki-laki. Berdasarkan hasil analisis, makna simbol yang dapat dilihat dalam bentuk pidato ini berupa bentuk sapaan yang mengandung rasa kekeluargaan, penghargaan, penghormatan, dan kedamaian. Selain itu, terdapat juga makna simbol berupa kue yang melambangkan pengharapan dan kesuburan.

Kedua, pada tahap pelaksanaan peminangan juru bicara pihak laki-laki diberi pertanyaan oleh juru bicara calon pengantin perempuan untuk dijawab dalam bentuk pantun. Makna simbol yang terdapat pada pantun menggambarkan harapan kedua pengantin terhadap hubungan mereka agar saling menyayangi, saling mengerti, saling memahami, saling menghormati, dan saling menjaga.

Ketiga, dalam doa, makna simbol berupa permohonan kepada Tuhan agar hadir memberkati rumah tangga anak perempuan mereka serta membimbing kedua pasangan ini menjadi pribadi yang sesuai dengan kehendak-Nya. 
Makna Simbol Dalam Prosesi Peminangan Di Desa Waenibe Kecamatan Fenalisela Kabupaten Buru Utara

Keempat, makna simbol yang terdapat pada nyanyian rakyat berupa gambaran kehidupan rumah tangga yang perlu dijaga keharmonisannya. Selain itu, terdapat makna simbol yang berupa ajakan kepada pengantin perempuan agar menghormati orang tua suaminya. Makna simbol dalam nyanyian rakyat juga berupa permohonan agar Tuhan hadir memberkati rumah tangga anak mereka.

\section{E. DAFTAR PUSTAKA}

Ghozali, Abdul Rahman. 2010. Fiqh Munakahat. Jakarta: Kencana.

Moleong. 2012. Metodologi Penelitian Kualitatif: Edisi Revisi. Bandung: Remaja Rosdakarya.

Poerwadaminta, W.J.S. 1993. Kamus Umum Bahasa Indonesia. Jakarta: Balai Pustaka. 
Makna Simbol Dalam Prosesi Peminangan Di Desa Waenibe Kecamatan Fenalisela Kabupaten Buru Utara 